\title{
Alternative Modernity of the Princely states- Evaluating the Architecture of Sayajirao Gaekwad of Baroda
}

\author{
Niyati Jigyasu \\ Chitkara School of Planning and Architecture, Chitkara University, Punjab
}

Email: niyati.jigyasu@chitkara.edu.in

\section{ARTICLE INFORMATION}

Received: August 17, 2017

Revised: October 09, 2017

Accepted: November 21, 2017

Published online: January 01,2018

Keywords:

Asian modernity, Modernist vision, Reforms, Architecture

DOI: http://doi.org/10.15415/cs.2018.52004

\begin{abstract}
The first half of the 20th century was a turning point in the history of India with provincial rulers making significant development that had positive contribution and lasting influence on India's growth. They served as architects, influencing not only the socio-cultural and economic growth but also the development of urban built form. Sayajirao Gaekwad III was the Maharaja of Baroda State from 1875 to 1939 , and is notably remembered for his reforms. His pursuit for education led to establishment of Maharaja Sayajirao University and the Central Library that are unique examples of Architecture and structural systems. He brought many known architects from around the world to Baroda including Major Charles Mant, Robert Chrisholm and Charles Frederick Stevens. The proposals of the urban planner Patrick Geddes led to vital changes in the urban form of the core city area.

New materials and technology introduced by these architects such as use of Belgium glass in the flooring of the central library for introducing natural light were revolutionary for that period. Sayajirao's vision for water works, legal systems, market enterprises have all been translated into unique architectural heritage of the 20th century which signifies innovations that had a lasting influence on the city's social, economic, administrative structure as well as built form of the city and its architecture. This paper demonstrates how the reformist ideas and vision of an erstwhile provincial ruler lead to significant architecture at the turn of the century in Princely state of Vadodara.
\end{abstract}

The population of India in 1931 numbered 340 millions, and of these one quarter, over eighty millions, are the subjects of princes. India contains close to two million square miles. Of these two-fifths lie in the princely states. The area of Great Britain is 88,000 square miles, its population 45 millions. In these simple terms the importance of the subject lies revealed.

(Sir George MacMunn, 1936)

\section{Background}

Modernization is an attitude, based on the perception that the change away from the past is needed in order to make a better future. 'Modernization' as a technical term was introduced only in the 1950s, but the initiation of modernization process goes back to nineteenth century. Though its seeds were sown in Europe, and spread all over, the regional outcomes were diverse. The Indian subcontinent was largely under the influence of the British during this period and was experiencing significant political, social and cultural changes which lead to architectural innovations in many regions. Although these were influenced by the colonial rule, the colonial architecture did not simply replace the local architectural character of the region. Sir Christopher Wren rightly said, "Architecture has its political use, public buildings being the ornament of a country: it establishes a nation, draws people and commune and makes people love their native country...”. Rulers or leaders in any era are indeed the principal facilitator of changes and India was no exception. Although the British ruled most of India, there were a number of small states that were independent and were ruled by local princes. After the East India Company, the British created the provinces, and the princely states were kept separate with consideration only for the administrative convenience of the British and the political need of that period.

The map of India during the Colonial rule is distinguished by two colours representative of two India's, known as the 'British India' and the 'Indian' India. The 'Indian' India include the princely states that consisted of two-fifths of the territory making onequarter of the population of the entire country outside the direct jurisdiction of the colonial state. Even with this, ethnocentrism with only consideration to the ideology of 
Orientalism, their contribution to the development was identified with 'British India' alone (Singh, H. 2007). As far as historians are concerned, the discussions of the princely states have been restricted to politics of the alliance system and indirect rule, military conquest, the hagiographies of princes, nationalist endeavours and accession issues during the 1940s. Not much has been talked about the idiosyncratic attempt to the development of their independent territories (Waltraud, E. \& Biswamoy, P. 2007).

The Princes usually inherited the throne and the government from their fathers. Since they were natives, they followed local culture and value systems -- even though they had to depend on the British for their own security and well-being. The princely States of India and their relations with the British Government has no parallel or analogy to any institution known to history. It was neither feudal nor federal, though in some aspects it showed similarities to both. Most of the states depending on their size had a British resident stationed in the state and he had an active role in the basic welfare of the state. Some of the princes, their ministers and at times the British residents were progressive in their approach and would encourage various developmental reforms in their territories. An 'alternative' modernity to the one that prevailed in British India was arising in the attempts by princes to live up to and at times, even surpass the modernizing expectations of British officials and of the increasingly Western-trained Indian elite, as well as the scholars' hopeful attempts to reconstruct rulers' internal policy measures as evidence of their enlightened governance (Waltraud, E. \& Biswamoy, P. 2007). Furthermore, the rulers' also were required to legitimize their position in front of their subjects and especially to the members of the indigenous elite. These were the people who became the agents of modernization and consequently determined the architecture of the period.

This paper examines the revolutionary ideology of one such ruler, "Sayajirao Gaekwad" of the erstwhile Princely State of Baroda and the result of his reformist agenda that led to some significant early 'modern' architectural works of this period.

\section{Reforms and their Implications on Architecture in the Princely States}

\subsection{The Reforms of 19th Century}

As mentioned earlier, the second half of the nineteenth century saw India divided into areas directly ruled by the British called the Presidencies, and the Princely states. The princely states (Fig. 1) were five hundred and sixty five (565) in number and majority of them had entered into an agreement with the Viceroy of India to provide public services and tax collection. Among these, twenty one had their own governments, and only four of them were large states of Hyderabad, Mysore, Baroda and Jammu \& Kashmir.

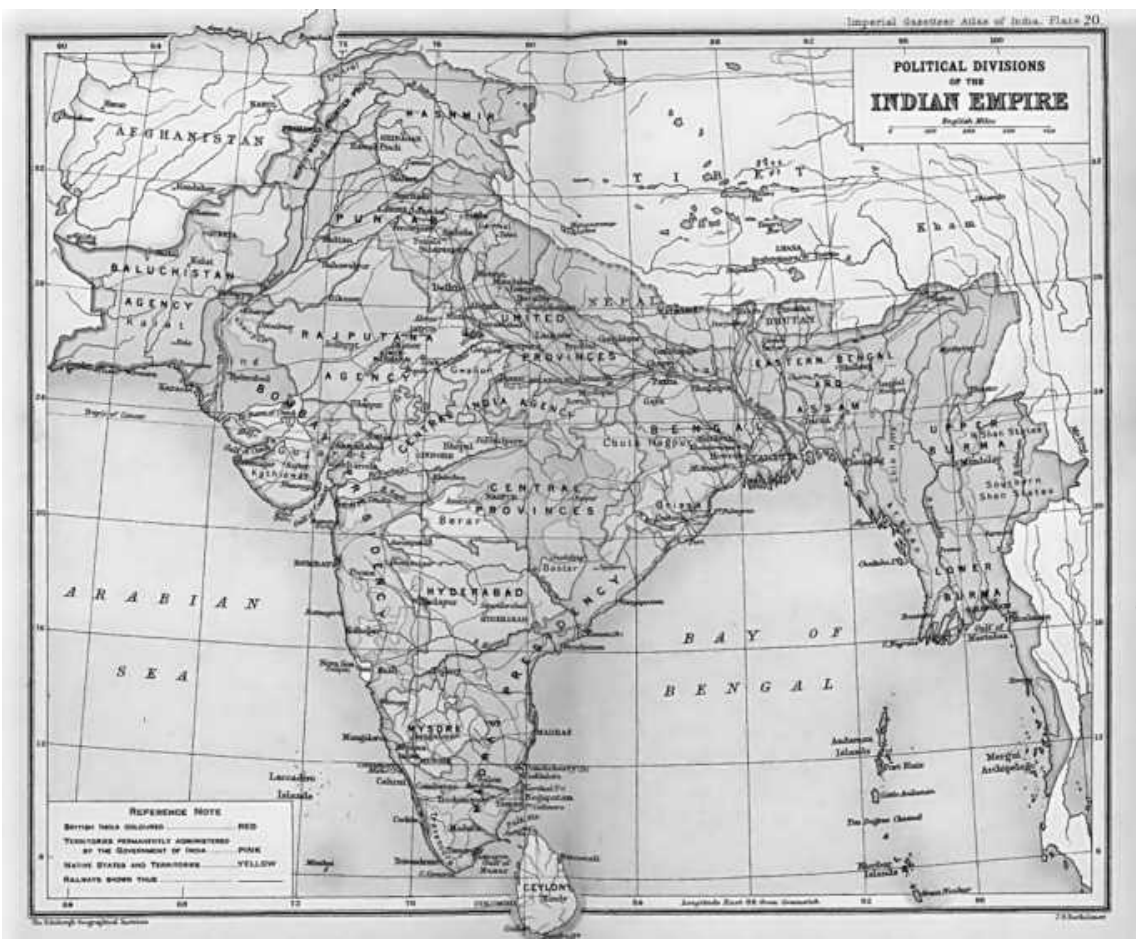

Figure 1: Political Divisions of Indian Empire (Image Source: Wikimedia.org, 2013). 
The British initiated various development works in the main cities of Presidencies like Bombay, Madras, Calcutta, and Rangoon and these became the models for emulation for the other regions. The changes included political organizations, social reforms and architecture, which led to the introduction of new technologies, social institutions and bureaucratic government structures especially towards the latter half of the nineteenth century. This led to states such as Travancore, Mysore and Baroda establishing departments of public works and education from the mid-nineteenth century. In the princely states, the British established schools for the education of the princes and in some privileged states, personalized tutors were also appointed. The perceived goal was to encourage princes to modernize, to educate their sons and train them in philanthropy, etiquette and sport, especially cricket and at times to instigate reforms and develop educational institutions promoting liberal traditions while simultaneously maintaining a feudal system (Lang, J., Desai, M. \& Desai, M. 1997). Some of these princes also travelled abroad and studied the reforms and policies of the places they visited. Efforts were then put in to try to reproduce similar possibilities wherever applicable in their states. When opportunities for Indians were limited in the Indian Civil Services, some Indian nationalists joined the administrations of princely states where they could demonstrate their administrative competence and exercise significant executive power. Also there were administrators like Madhava Rao, who acquired wide fame for his work with modernising Travancore, and later on Indore from 1873 till 1875 and Baroda from 1873 till 1875 (Ramusack, B. 2008). All this resulted in requirement of various buildings like law courts, administrative offices, commercial enterprises such as insurance companies and trading houses. Housing projects also became important due to influx of people into the urban areas.

The deviations that can be seen in the dominion of various princes pre 1947 indicate the possibilities of a certain level of autonomy in their realm. Even though environmental and historical aspects were significant, individual initiatives were vital. The rulers in three distinct geo-cultural spheres - the coastal Travancore and Cochin, the peninsular Mysore, and the plains of Baroda - were able to build highly centralised, bureaucratised governmental structures that led to major improvements in the lives of their people through increased literacy, opportunities for government employment, and at times changes in land revenue rates (Ramusack, B. 2008).

\subsection{Implications on Architecture of the Period}

The architecture of this period was based on mainly three drivers. The first was the continuous amalgamation of visionary ideology of the princes, ministers and at times the British residents of the state leading to need for the architectural built forms. The second was the scale and language of the architecture of this period built with the intention to be assertive and reflective of a state. Hence even ordinary buildings like educational colleges were made to look monumental to enhance the importance of them as being unique ventures for that period. The third and very crucial driver was the possibility of employing various British architects including Swinton Jacobs, Major Charles Mant, Robert Chisholm, Charles Frederick Stevens and many others who worked for the princely states at one time or another. At times, the Diwans (ministers) would be shifting their base from one province to another. This resulted in the similar typology of buildings coming up in various parts of India as can be seen from the example of Travancore (modern Trivandrum) and Baroda. Baroda is exemplified by all the drivers and credit for this mainly goes to three individuals; Sayajirao Gaekwad, the visionary rule and Charles Mant and Robert Chisholm, the two architects behind majority of the projects. Some of the early British interventions in India led to the development of architectural style that was based on the pattern books used by the builders and architects in Europe. However in princely states it was primarily vernacular in inspiration which lead to regional variation from one State to another. The 1850 's saw a major upheaval in Indian political and architectural history. This was the time when development in communication and manufacturing technologies became more evident in India. The revolt of 1857 made the Britons realise the importance of knowing India to rule India (Lang, J., Desai, M. \& Desai, M. 1997). This brought about the need to incorporate Indian design elements into their architecture. As Thomas Metcalf, an expert on the subject says that it was critical that in all the buildings during the British Raj, the imperial position of the British is clearly visible as they were direct representative of the empire. In order to legitimize the rule, the use of local architectural vocabulary was also seen (Metcalfe, Thomas R. 1982).

This resulted in the development of Indo-Saracenic architecture as a synthesis of Mughal, Hindu, Buddhist and Gothic motifs developed by British architects in India. The main characteristics of this architectural idiom were onion (bulbous) domes, overhanging eaves, pointed, cusped or scalloped arches, vaulted roofs, domed kiosks or chatris $^{1}$ (cenotaphs), towers or minarets, harem windows, open pavilions and pierced open arcading. The architecture of the princely states of the British India in the latter half of the nineteenth century has great historic significance. These regions in many ways facilitated the development

${ }^{1}$ Chatris: Mughal and Hindu term for a domed kiosk on the roof of a temple, tomb or mosque. The domes are usually supported on four columns 
of a unique architecture made up of the cultural synthesis of the colonial and the indigenous forms. This developed into a sophisticated and mature form as Indo-Saracenic architectural style and in turn exerted an influence over wide geographical areas in other parts of India.

This architectural style is predominantly seen in Baroda, Bombay, and Madras (Jeyaraj, G. 2011). Robert Chisholm, an ardent follower of Indo-Saracenic idiom came to Baroda in 1881. Prior to this, he was based in Madras and was engaged with many important public buildings there like the senate house and central railway station. Major Charles Mant was the state architect with Baroda. Baroda became a showcase of the Indo-Saracenic style for both these architects whose combined works changed the skyline of Baroda in the span of 25-30 years. This would be discussed in detail in the following section.

\section{Baroda State and its Process of Modernization under Sayajirao III}

India contains no more than two great powers, British and Marathas, and every other state acknowledge the influence of one or the other. Every inch that we recede will be occupied by them.

Charles Metcalfe, 1806

The end of battle of Panipat saw the Marathas power divided into four separate states; each dominated by one of the newly ascendant Maratha military houses. They included the Gaekwad in Baroda, Sindhia in Gwalior, Holkar in Indore, and the Bhonsle in Nagpur. Thus, at the turn of the twentieth century the Baroda State was an important princely state with its territories distributed into 5 different geographical pockets of the present day state of Gujarat (Fig 2). The Gaekwads were a Maratha family who ruled the State since capturing the territory from the Mughals in 1721. They had accepted protection from the British in 1802.

Sayajirao III Gaekwad was born in 1863 in a cadet branch of the family and at the age of twelve, with British approval, he was selected to be adopted as the heir of Baroda State. On directive from the British, the British tutor FAH Elliot, and Raja Sir T. Madhava Rao, were entrusted the job of giving him high-quality education and thorough training in the arts of administration. Sayajirao ascended the throne in 1881. His British education paved the way for his modernist approach to his task as ruler, and he distinguished himself as one of the most enlightened and progressive of Indian princes. Here it is also important to note that the seeds of changes were also encouraged by the visionary Diwan (Minister) Sir T. Madhava Rao, an ICS officer who was earlier posted at the state of Travancore in the south and it was his exemplary governance that set the stage for the growth. Sayajirao had a singleness of purpose and clear perception of what he needed, and pursued a policy of reforms in every sphere of public activity. When Sayajirao

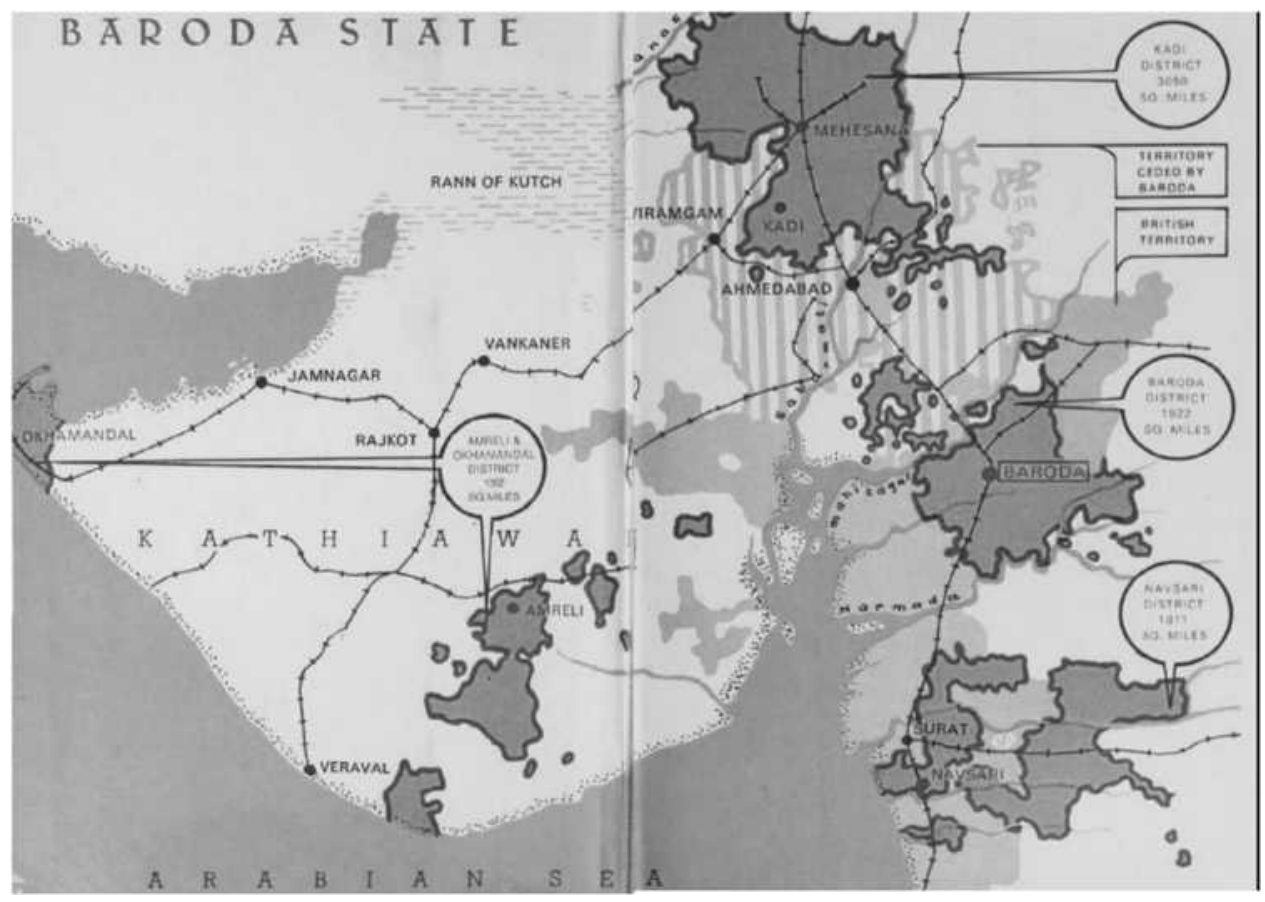

Figure 2. Baroda territories (Image Source:Gaekwad, 1997, p-3). 
came on the throne, his initial works were concentrated on education for his people, uplifting of the oppressed, and also judicial, agricultural and social reforms. He developed the Baroda's textile industry on a larger scale. His social reforms included banning child marriage, legitimizing of divorce and elimination of un-touch ability. He was also responsible for promotion of Sanskrit, ideological studies and religious education. He was a great promoter of fine arts and started the first music college. On the economic developmental mission, he established the railroad and founded the Bank of Baroda in 1908 existing even today. The establishment of the municipal corporation in the 1880's along with the Public Works Department (PWD) led to massive changes in administration process that would directly impact urban changes (Sergeant, P.W. 1928).

Along with the primary motive of development, he was also fully aware that modernist ideas and their implementation were very important to put his reforms into practice. He was continuously updated about the contemporary innovations and possibilities in the world in the form of social, political and technological advancements. Like other princes, he also carried out several extensive foreign tours especially to the United States and Britain during the course of which he made it his business to study the economic, social, political conditions and administrative policies of the countries he visited and tried to implement similar ideology wherever applicable to local conditions. He had an efficient governing council to advise him, well established legal system and various departments to carry out administrative work. Sayajirao Gaekwad also believed that he had to attract and invite the best possible talent and expertise available for building the new required infrastructure and institutions. This brought Architects Major Charles Mant and Robert Fellowes Chisholm, sanitation expert Baldwin Latham, landscape designers William Gold ring and librarian Borden. The renowned Town planner Patrick Geddes was also one of the many experts who had a direct impact on the urban interventions and transformation brought about in the city.

\section{Architectural and Urban Design Initiatives in Baroda}

Though history of Baroda can be traced back to more than 2000 years, the architecture seen today has three important layers. The first is the Islamic layer of the walled city of 'Daultabad' built in the 15 th century. This was followed by the Maratha period showcasing the vernacular architecture from that period. But architecture came to a prominence from the 1870s until 1930's as this was the time when Baroda got consolidated as a major state. Administrative organizations and proper revenue collections gave ample scope for various developments. This was further fuelled by
Sayajirao's visionary ideas and his able administrators that led to the development of various architectural and urban design projects that are outlined below.

\section{Educational Buildings:}

Sayajirao Gaekwad considered education as fundamental for development of people particularly women. Adult education and women's education were encouraged and he was also the first to introduce the idea of mobile library. Sayajirao III saw the educational institutions as means of formal education while libraries were seen as places of civic education. According to Sayajirao Gaekwad, "Education requires as an essential supplement to it, a system of free libraries that would keep literacy alive and aid men and women in rural areas to have access to sources of knowledge" (Gaekwad, F. 1989). The library movement was a pioneering endeavour in this part of the world. It was path breaking and remarkable, an approach where 200 plus libraries were set up in the larger territory of the state of Baroda available to all irrespective of caste, class, colour, creed, social status or any other differentiating characteristic (Nagar, M. 1992). These included travelling/mobile libraries. Following educational buildings are worthy of mention:-

- The State library(1876)

- Anglo Vernacular Boys School (1886)

- Baroda College(1887)

- Female training School/Girls School(1888)

- Zenana girls School (1895)

- Central library(1910-11)

\section{Recreational Infrastructure}

Sayajirao's contributions also included public parks and the zoological gardens that were contemporary to the European counterparts of that time. One of the main parks, Kamati Baug, also includes the Baroda museum. The museum and picture gallery was designed by Chisholm in consultation with Major Mant. They were intended for welfare and education of his people and, Sayajirao acquired the invaluable artefacts himself or entrusted the work to various scholars and art connoisseurs. Significant works include Kamati Bagh, Baroda Museum \& Picture gallery (1894), Planetarium and Jubilee Baug(1930).

\section{Administrative Buildings:}

The reformist changes in the law and administrative systems brought about the construction of Nyay Mandir or the temple of justice in the centre of the city in 1896. Other administrative buildings include the Land revenue building (Fig 3) and Baroda archives (Fig 4) commissioned for record keeping (1896). All were part of the Chisholm's projects. The Khanderao market constructed between 1905 and 1915 is a planned market building for vegetables that also has 


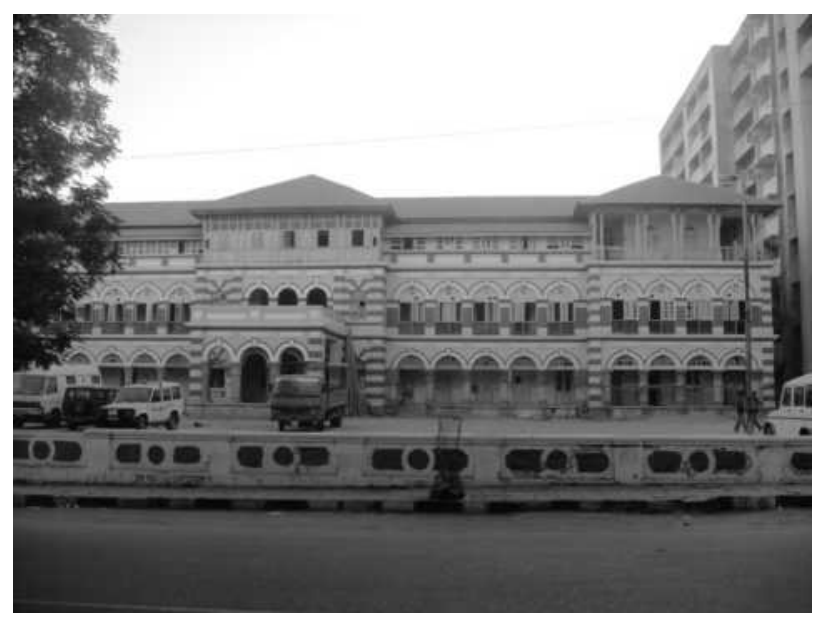

Figure 3. Land Revenue Building (Image Source: Author, 2011).

municipal offices on the first floor. Kothi-Kacheri is another significant administrative building constructed during this period.

\section{Other public works}

On lines of the prison reforms being studied world over, Sayajirao ordered the preparation and publication of a jail code. This included clean environment for stay, employment of prisoners and opening of separate reformatory for juvenile delinquents. Under the new administration, a central jail was opened in 1881. Other public works also include the Ajwa water reservoir and largest narrow gauge railway line.

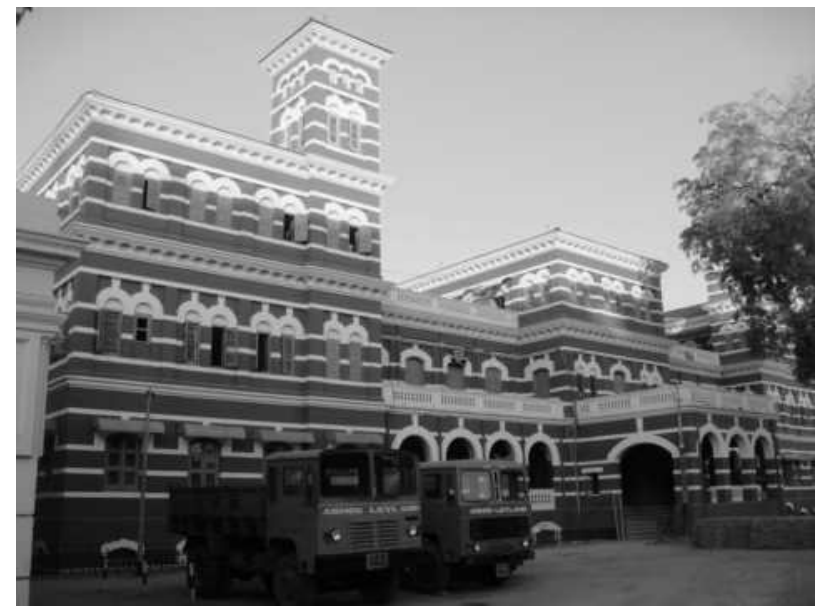

Figure 4: Baroda Archives (Image Source: Author, 2011).

\section{Urban design and Landscape:}

Sir Patrick Geddes, the renowned town planner visited India a number of times. Between 1915 and 1919 Geddes wrote a series of "exhaustive town planning reports" on at least eighteen Indian cities. Through these reports, Geddes was concerned with interventions in and plans for the urban fabric that were both considerate of local context and tradition and awake to the need for development. Geddes was also invited to Baroda by Sir Madhava Rao to analyse the existing scenario and suggest the remedies. The study area included the axially planned walled city and the area outside it (Lang, J., Desai, M. \& Desai, M. 1997).

\section{Private Projects:}

Sayajirao also patronised a few private works that are significant examples of Indo-Saracenic style of architecture. These include extension to the Nazarbaug Palace undertaken in 1890 and Laxmi Vilas Palace (1890-95). (Fig 5)

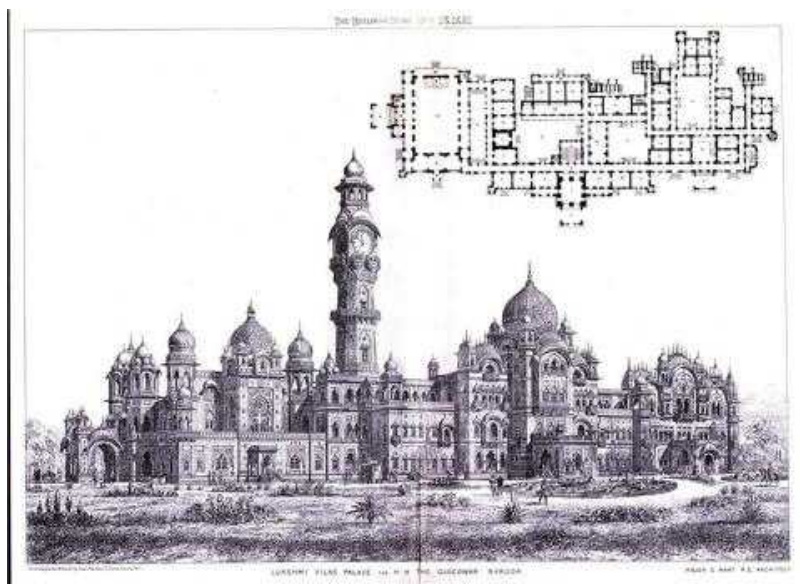

Figure 5. Laxmi Vilas Palace (Image Source: Gujarat history, 2015).

\section{Architectural and Urban Design Characteristics of Significant works The Maharaja Sayajirao University}

On the Diamond Jubilee anniversary of his accession to the throne, Sayajirao Gaekwad allocated large funds from his personal as well as state funds to set up the Baroda College for benefitting the students from the rural areas of his state. The work of designing this building was given to Robert Chisholm. This Building is the most ambitious project of Chisholm in Baroda \& one of the finest buildings constructed in India during the late $19^{\text {th }}$ century- both in the territory of British India or the Princely States. The scale of this building clearly demonstrates that Chisholm wanted to design a building that would become a centre-piece of the architecture of Baroda State.

Chisholm always worked with simplicity of plans. For Baroda College, Chisholm designed the building as a continuous set of rooms with surrounding corridors covering a courtyard in the middle. The corridors are covered on the sides by jalis ${ }^{2}$, typical of the local architectural style,

${ }^{2}$ Jalis: An Indian term for a perforated screen, usually with an ornamental pattern, in stone or wood. 
and show the climate sensitive planning of the architect (Fig 6). Similar two configurations were connected through a central hall that in case of Baroda served as the coronation hall. Similar planning can also be seen in other buildings of the same era such as the Mohindra ${ }^{3}$ College in Patiala.

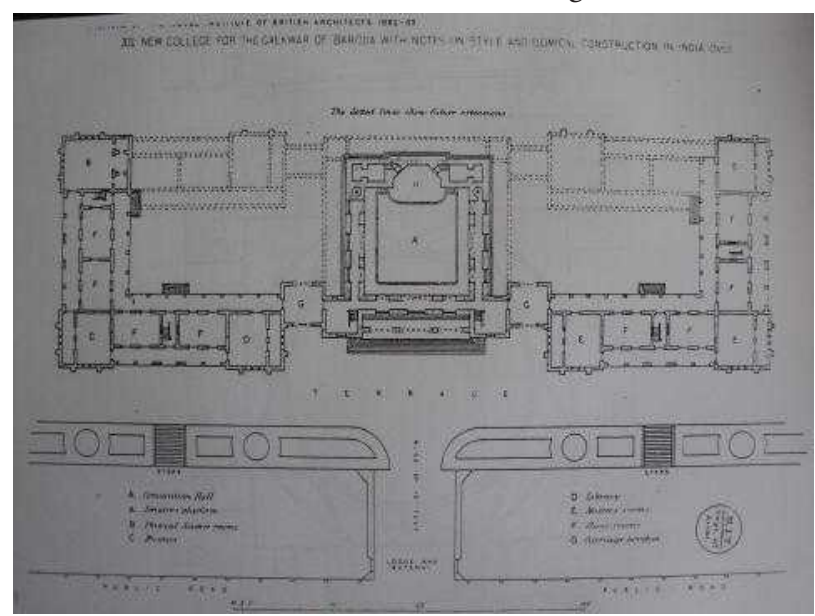

Figure 6. Plan of Maharaja Sayajirao University (Baroda College) (Image Source: Ar. Sanjeev Joshi, 1990).

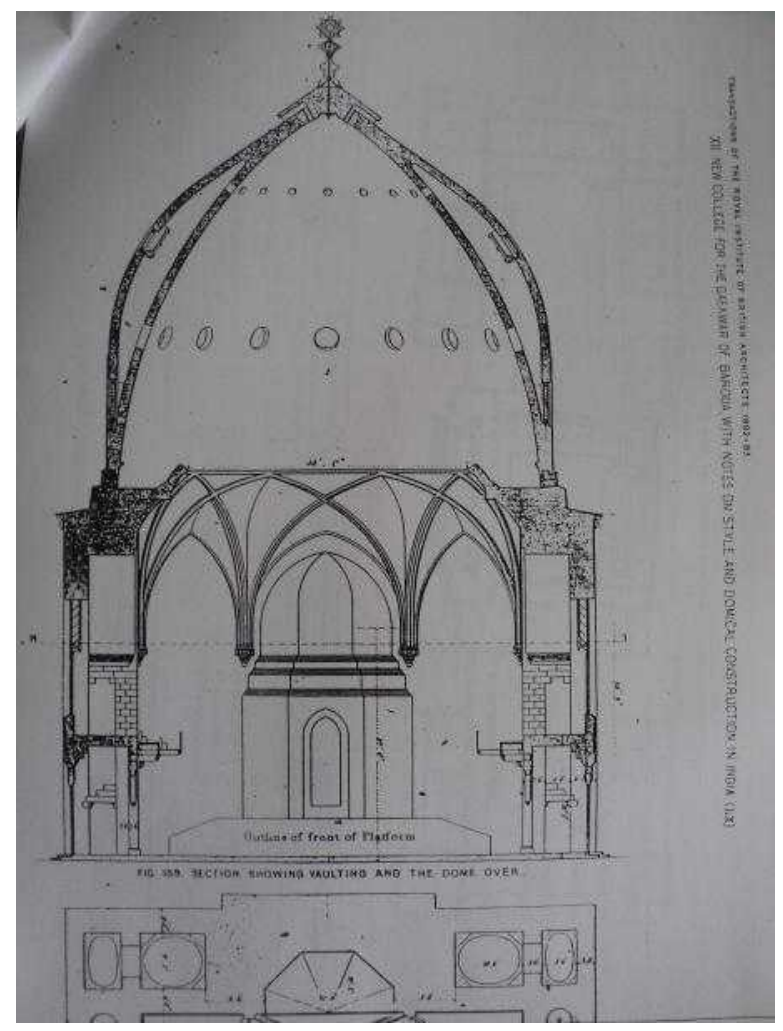

Figure 7. Section of Dome(Image Source: Ar. Sanjeev Joshi, 1990).

\footnotetext{
${ }^{3}$ Wada architecture: The traditional residential form of Marath architecture, and have a continuous corridor in front supported by columns with wooden railing in between.
}

Chisholm's structural engineering of the dome is the most striking aspect of this building. "The true dome, as far as I know, is a novelty", an idea expressed by Chisholm when he gave rise to this 70 feet diameter dome for the Baroda College. What started off as an informed response to the climatic conditions of Baroda, were later seen as stylised elements within his buildings (Joshi, Sanjeev 2015). It is a twin-dome structure where in 16 ribs created between the inner \& outer dome- becomes the key skeletal members holding the 45 metres span of the dome (fig 7). The twin domes system also enables the natural ventilation of the dome $\&$ details of apertures in the dome have been cleverly worked out to exit the rain- water. The dome is the second largest dome in India and largest for any institutional building and towers to a height of 144 feet. There are 6 other domes in this building in the 2 wings that define courtyards etc.

The main entrance to the building is a triple arch of stone capped with finials borrowing the architectural vocabulary of Buddhist Chaitya ${ }^{4}$ (Fig 8). Another Buddhist vocabulary is the use of carved elephants as column capitals. The building has been put on a plinth/ platform of about 4-5 metres. The entire complex is done in redbrick and tiled bands.

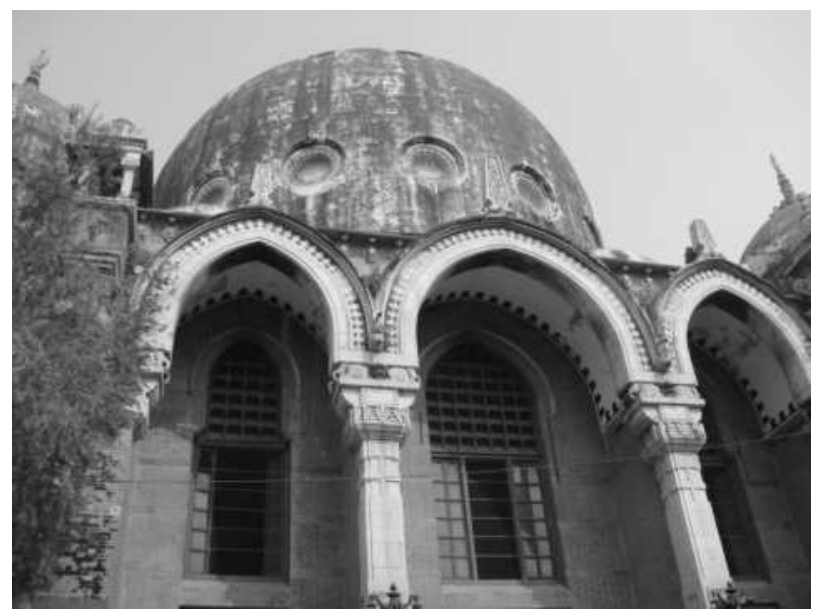

Figure 8. Triple Arch (Image Source: Author, 2011).

\section{The Central Library}

This building built in 1910-11 does not take any inspiration from the Indo-Saracenic architectural style that was so prevalent during this period. One of the first public libraries to be set up in India, it shares a unique resemblance to the Library of Congress, Washington, USA. On invitation of Sayajirao, William Alanson Borden, then Librarian at the Young Men's Institute of New Haven in New Jersey came to India in 1910 to plan this ambitious project. It is believed that along with Borden, Sir Edward Lutyens (The architect

${ }^{4}$ Chaitya: A Buddhist shrine including a stupa. 
behind the planning of central administrative areas of New Delhi) as well as three architect-planners from Baroda State were involved in the design of this building. The exterior of the building is characterised by the a wide corridor a feature comparable to the Wada architecture of the Marathas and filters the noise and dust of the street outside from the main well of the library with its lending and receiving counters, to see book-filled shelves and cupboards arranged methodically all around.

Two light wells filter natural sunlight into the interior thus brightening up the vast space (Fig 9). The stack rooms are very unique with three floors -85 feet long, 34.5 feet broad, with 352 slotted angle racks that can house 3.5 lakh books. The stack house is designed as a warehouse with long, glass-paned windows oriented to the north-south axis thus getting the maximum daylight. They have a distinctive iron shelf-rack and glass flooring system that is disasterproof, allow for as much natural daylight as possible and, most importantly, are extremely user and book-friendly (Fig 10).

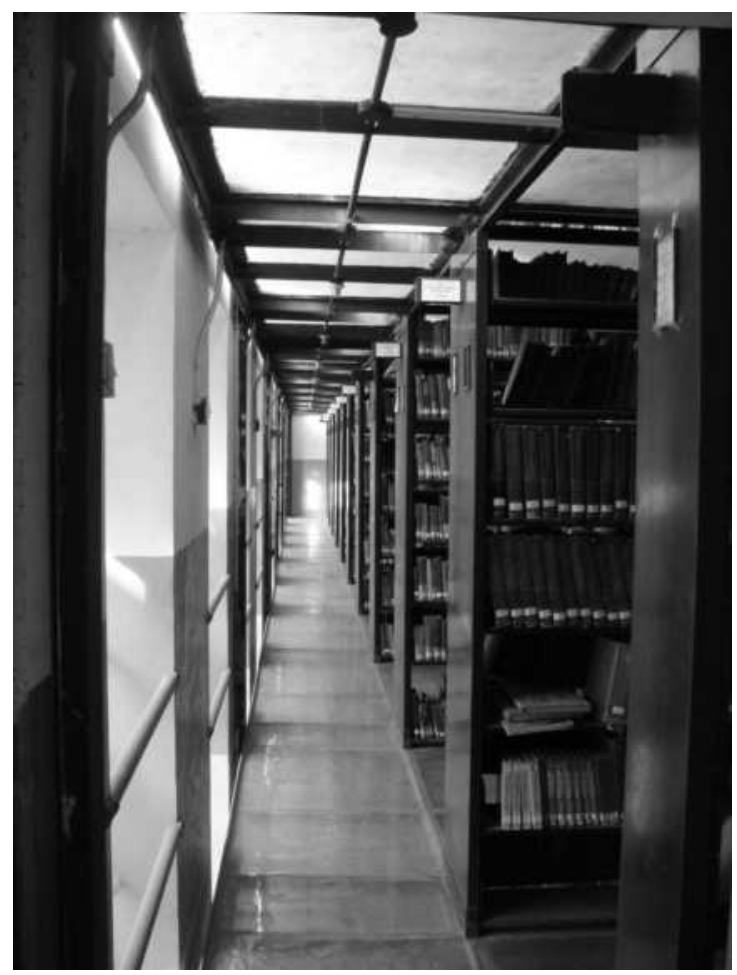

Figure 9. Light well corridors with flooring in Belgian tiles(Image Source: Author, 2011).

The wooden roof structure has iron girders that are designed to hold up the entire metal stack armature. Each stack is fitted three feet away from the wall with thin running beams holding each one in place, with the beams screwed on into the metal armature concealed in the wall. The stacks are separated from each other by a meter, so that browsers have enough personal space as they look for the books they want. The entire structure was designed to exact specification and executed by J. Snead \& Co., USA, who also designed the Library of Congress, Washington. While the ground floor has kota (a local stone) stone tiles, the upper three tiers are fitted with 719 large glass floor tiles, 2 inches thick imported from Belgium at that time. These tiles ensured that the metal armature and shelves on which the books are stacked do not heat up in the summer and freeze in the winter, thus keeping the books stocked at an even temperature. The main construction materials of the building include wood, bricks, cement, steel and copper. The building is designed as disaster resistant structure and experienced only minor shaking of the roof during earthquake.

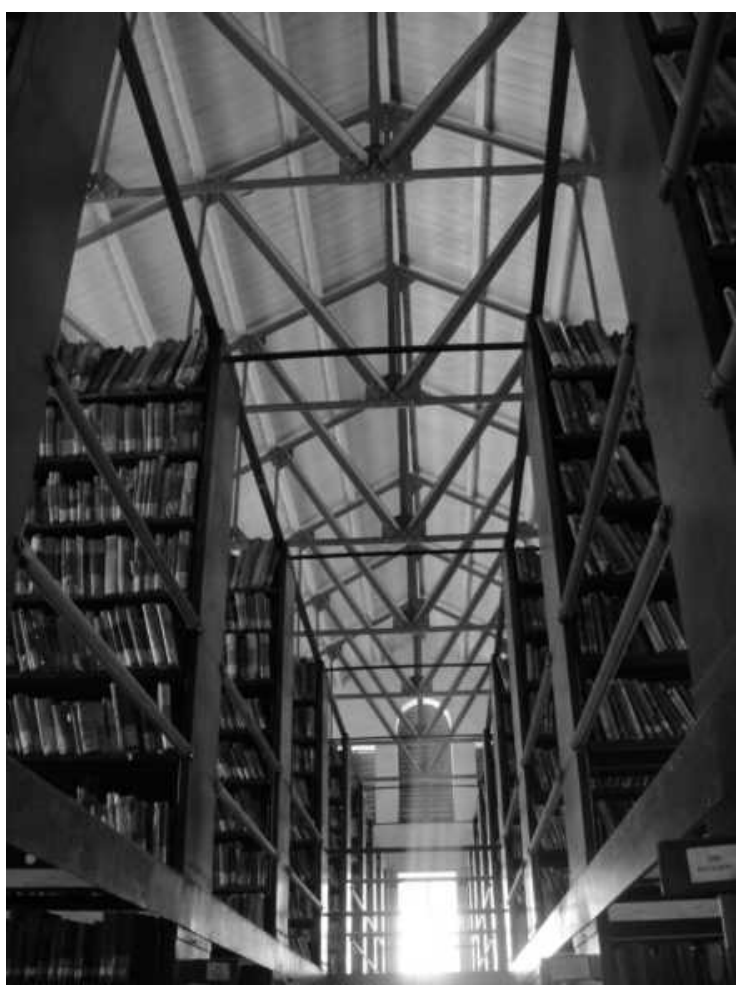

Figure 10. Stacks and truss systems (Image Source: Author, 2011).

\section{Baroda Museum}

The museum and picture gallery with total floor area of 40,000 sq. ft. are two buildings built in the prevalent IndoSaracenic style. With respect to form, Though the form do take from the local Maratha architectural vocabulary of wooden framework filled with brick walls, the ground floor showsa pure European style that includes a cornice decorated with Parthenon frieze in plaster. The porch on the south is ornamented with early and later Mughal forms. The gallery is planned in European brick style with columns and 
open pavilions on the roof. The most interesting feature is the church nave like double heights to enable indirect light to enter the museum. The interior of the main building has its first floor galleries projecting over the double height space that is structured by the trusses that span above it (Fig 11).

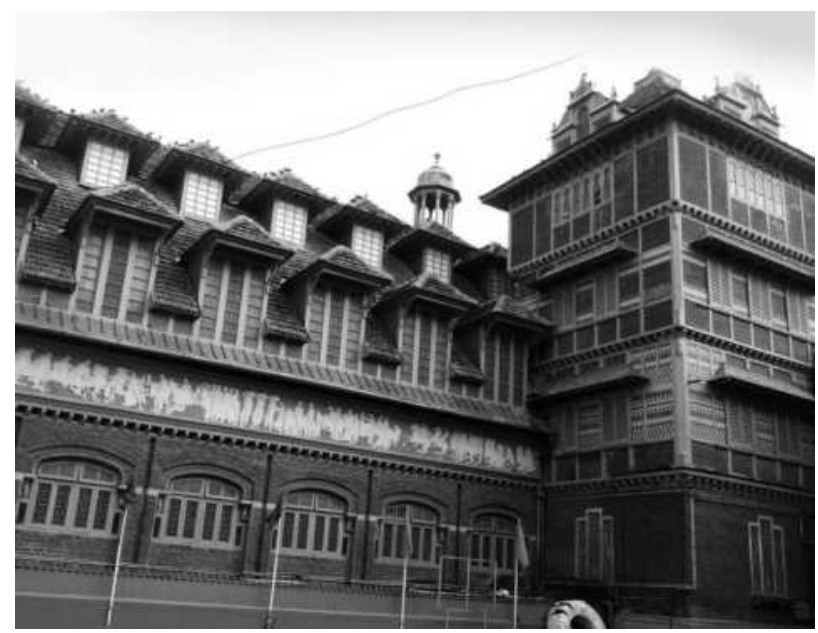

Figure 11. Baroda Museum with the church nave like openings and Fresco (Image Source: Author, 2011).

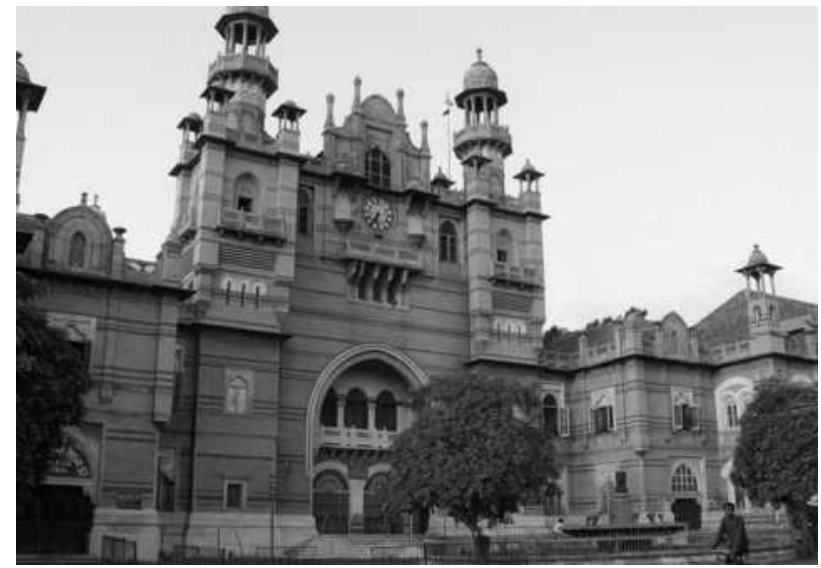

Figure 12. NyayMandir (Temple of Justice) (Image Source: Author, 2011).

\section{The NyayMandir (Temple of Justice)}

This was another assignment by Robert Chisholm. The Nyay Mandir (Fig 12) building has duality in its facade that results in the exterior being cladded with ceramic tiles while the inner courtyards are left with exposed brick masonry finish. The town hall has a trussed roof for double heights and better ventilation. In the center of the building is a large hall decorated with mosaic work. It contains a statue of Maharani Chimnabai, the first consort of the Gaekwad Maharaja SayajiRao III (ruled 1875-1939), after whom the building was named. The Nyay Mandir has elements derived from the Ibrahim Rauza (1626) at Bijapur. The building also has slender minars and chattris. In all his work Chisholm was not simply copying elements but seeking to translate them into a harmonious whole.

\section{Central Jail}

The design of this jail was based on the concept of 'Panopticon', a typology that originated in Paris and was well established in Europe during this period. This prison design allowed a centrally placed observer to survey all the inmates, as prison wings radiated out from this central position. This concept was developed by Bentham in 1871("Panopticon", n.d.). Another variation of this was the separate system for prison (Fig 13). This plan included a central hall, flanked by many (from four to eight) radiating wings of prison wings. These are detached from the main hall and each other by large metal bars. This system ensured that all prison blocks could be seen from the centre though individual cells can be seen only after entering the individual blocks ("Separate system", n.d.). The cells are radiating from the central zone on the ground floor, with plenty of light and air. This design was later emulated across many of the colonies of the British and the French.

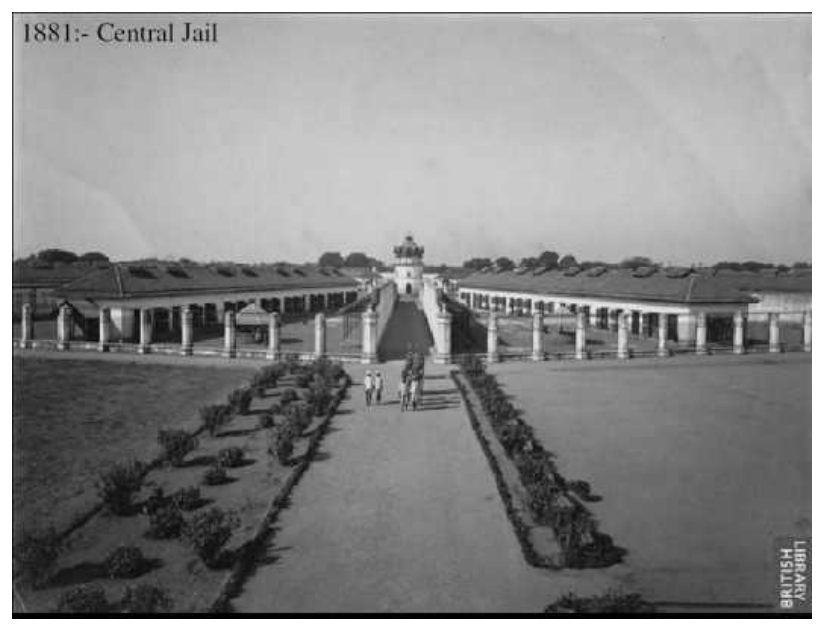

Figure 13. The Central Jail (Image Source: British Library archives, accessed on 5th July' 2012).

\section{The urban design interventions}

Baroda urban scale went through a major upheaval as a result of the monumental scale of the buildings coming up during this period. The Sursagar was originally a local water body just outside the walled city. With the arrival of Chisholm and other architects, the area around it was replanned and demolitions and interventions thought about. This led to the transformation of this local water body to an important element of urban design and the area became an urban city space with very important institutional buildings 
like the Nyay Mandir and Music College coming up around it (Fig 14a-14b).

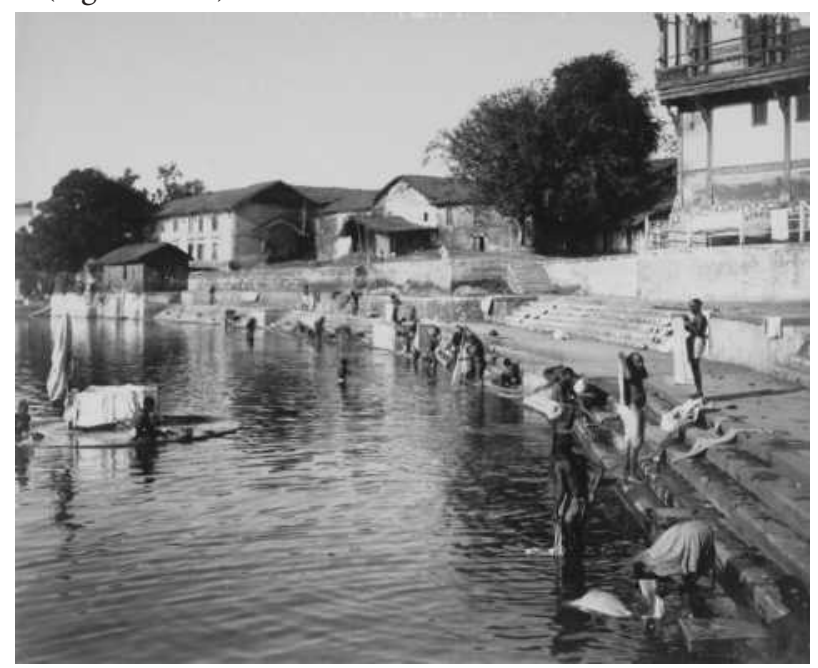

Figure 14a: Sursagar water body in 1800 (Image Source: British library archivesaccessed on 5th July' 2012).

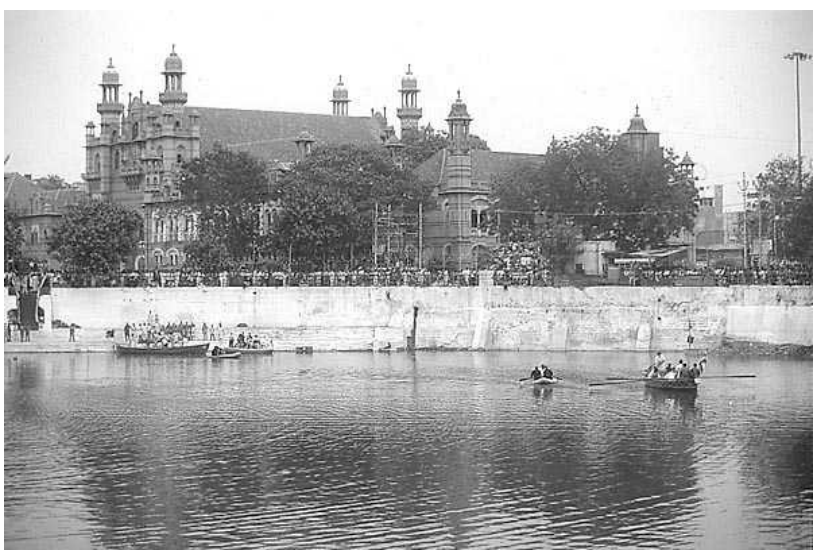

Figure 14b. Sursagar today (Image Source:Author, 2011).

Patrick Geddes stayed in Baroda on two occasions in 1915. His findings and suggestions were submitted in a report, "A report on the development and expansion of the city of Baroda" that was later published by the Lakshmi Vilas press in 1916. The series of changes proposed by him in the report were only executed after 1930 . Two of the major changes included decongestion of the area around Sursagar and the Mandvi, the central clock tower in the walled city. Green pockets in from of garden were introduced around Sursagar. For Mandvi, the central area was congested due to vehicles and population influx by end of the 1870's. As per Geddes he suggested that the area be opened up by aligning the shops in a crescent form with a narrow passage by which pedestrian could turn the right angle from one street to other, without the danger of coming out onto the street suddenly. This led to creation of circular arcades on the two sides of the MG road (Fig15a-15b). He gave guidelines for improvement of the quality of life in the pols ${ }^{5}$ through his concept of 'Conservative Surgery'. This concept mainly talked about decongesting the lanes, filing the holes with waste material, creating green spaces and improvement of built fabric all with community participation. He also suggested preservation and restorations for the traditional gates from the Islamic period with the possibility of having additional exits and inlets as the traffic may render necessary(Geddes, P. 1916).

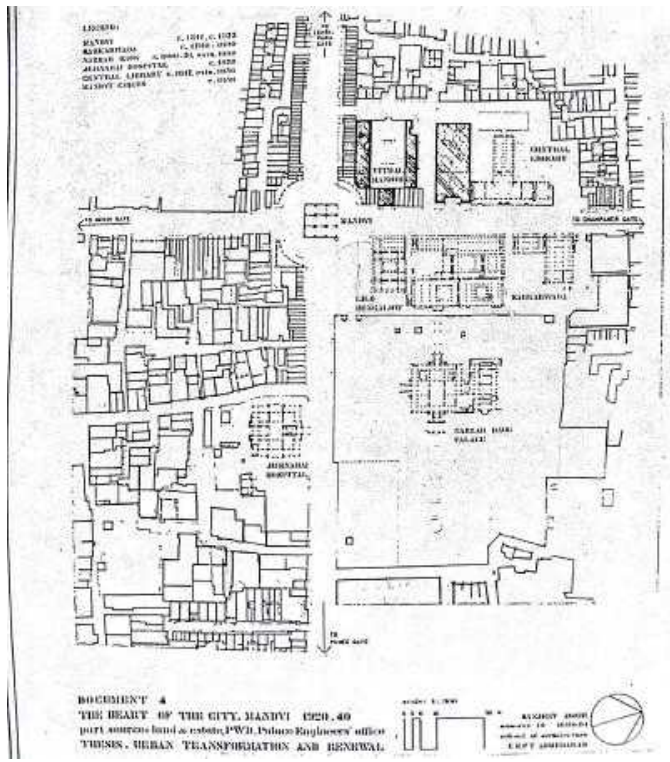

Figure 15a: Mandviplan in 1920- post introduction of arcade around the clock tower (Image Source: Ar. Sanjeev Joshi, 1990).

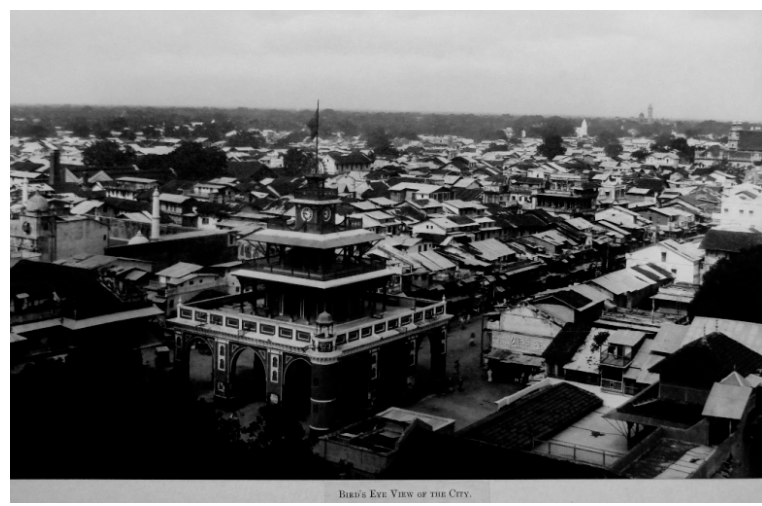

Figure 15b. Mandvi plan in 1800 (Image Source: gaekwadsofbaroda.com)

\section{Conclusion}

"The Triumph of machinery has been the triumph of our age: the victory of steam and electricity will always be memorable

${ }^{5}$ Pol: A lane as seen in cities of Gujarat. 
among the decisive battles of the world." Sayajirao Gaekwad (1906, Address at Industrial Conference, Calcutta)

The late nineteenth and early twentieth century in India witnessed the architects pushing the envelope as well as keeping the traditions alive. Architecture as an emblem of power was for centuries endorsed through patronage. This was the time when British and the local rulers were most instrumental in determining the path that a city/state would take in terms of its architectural and urban form. This successful culmination can be seen in Baroda. Sayajirao III changed the expression of Baroda from a medieval city to a state capital through reforms that were aimed at bringing about socio-cultural change. Also, as mentioned before he had the ability to understand the need of experts to implement his vision. This can be attested by the various experts that contributed to Baroda like Robert Chisholm, Major Mant, William Goldring and Sir Patrick Geddes among many others. The central library showed his preference of architects who were qualified to design buildings according to specific functions. The disaster resistant structure of the central library is perhaps one of the earliest conscious design considerations in architectural project in India. At the same time, the town hall has an eclectic look and traditional features making it identifiable with the local people. The architectural concept of giving Baroda College prime significance in the city's architecture and urban form attest the importance given to education, a very path breaking reform at the time.

In fact, the development of the Indo Saracenic style of architecture during this period demonstrates a very significant stage in architectural history of the region through amalgamation of British and Indian architecture style. Baroda is an important exhibit area for this style and various works of Robert Chisholm, a very prominent architect of the 'modern' heritage of this period. This architecture changed the urbanscape of many cities in India forever leaving a distinct mark on the tangible footprint. A lot more research needs to be undertaken to understand the evolution of this architectural idiom.

Sayajirao's contribution did not end at the monument level. Urban planning was also given due consideration resulting in invitation extended to Patrick Geddes and implementation of his report carried out during the next 20 years. Today, though various layers can be seen in Baroda, the buildings designed and constructed during the late 19th and early 20th century have retained their authenticity and integrity in the form of their function and architectural vocabulary.

Though the architectural works mentioned need to be assessed and evaluated independently for their significance and condition, it will not be an understatement to say that the architectural works in Baroda undertaken during the transition period from late 19th to early 20th century played a very significant role in the history of architecture in South Asian region and needs to be given due recognition and appreciation for their reflection of the reformist, historical and geographical perspectives brought out by a visionary ruler, Sayajirao Gaekwad III.

\section{References}

[1] Gaekwad, F. (1989). Sayajirao of Baroda: The Prince and the Man, Bombay: Popular Prakashan.

[2] Geddes, P. (1916). Development and Expansion of the City of Baroda. Report published by Order of Governance: Lakshmi Vilas Press.

[3] Jeyaraj, G. (2011). Indo Saracenic Architecture in Chennai. Chennai: Hindustan University.

[4] Joshi, Sanjeev (2015). Robert 'Fellowes' Centennial Exhibition 2015, Vadodara, Indian architect \& builder, published by Jasubhai Media Pvt. Ltd, Mumbai, 38 , May 2015, 28(9).

[5] Lang, J., Desai, M. and Desai, M. (1997). Architecture and independence: The search for Identity-India 1818 to 1980. Oxford University Press.

[6] Laxmi Villas Palace (2012). Maharaja Sayajirao Gaekwad III. gaekwadsofbaroda.com accessed May'2014.

[7] Metcalfe, Thomas R. (1982). A Tradition Created: Indo-Saracenic Architecture under the Raj,Published in History Today 32 Issue: 9.

[8] Nagar, M. (1992). Shri Sayajirao Gaikwad, Maharaja of Baroda: The Prime Promoter of Public Libraries, 25

[9] Ramusack, B. (2008). The Indian Princes and their States, Cambridge Histories Online: Cambridge University Press, 197-198, 218.

[10] Sergeant, P. W. (1928). The Ruler Of Baroda ; An Account Of The Life And Work Of The Maharaja Gaekwar. John Murray London: Universal Library.

[11] Singh, H. (2007). Colonial and postcolonial historiography and the princely states'; 'Indian princely states, People, Princes and Colonialism edited by Ernst Waltraud and Pati Biswamoy: Routledge Publishers, 15.

[12] Waltraud, E. and Biswamoy, P. (Eds.) (2007). Indian Princely States: People, Princes and Colonialism Routledge, 7-8.

[13] Wikipedia. Separate Systems wikipedia.org/wikil Separate_system accessed March 2013

[14] Wikipedia, Panopticon' wikipedia.org/wiki/Panopticon accessed March 2013 